\title{
Effect of applying molasses or inoculants containing homofermentative or heterofermentative bacteria at two rates on the fermentation and aerobic stability of corn silage
}

\author{
C. M. Huisden, ${ }^{*}$ A. T. Adesogan, ${ }^{* 1}$ S. C. Kim,${ }^{* 2}$ and T. Ososanya ${ }^{*} \dagger$ \\ *Department of Animal Sciences, Institute of Food and Agricultural Sciences, University of Florida, PO Box 110910, Gainesville 32611 \\ †Department of Animal Science, University of Ibadan, Ibadan, Nigeria
}

\begin{abstract}
This study determined how the fermentation and aerobic stability of corn silage are affected by treatment with molasses or 2 dual-purpose inoculants applied at or above the recommended rate. Corn forage (DeKalb 69-70) was harvested at 39\% dry matter (DM) and ensiled after treatment with no additives (control, CON), molasses (MOL), Buchneri 500 inoculant, or Pioneer 11C33 inoculant. Molasses was applied at 3\% of forage DM. Buchneri 500 was applied at the recommended rate of $8 \mathrm{mg} / \mathrm{kg}$ fresh forage to supply $1 \times 10^{5} \mathrm{cfu} / \mathrm{g}$ of Pediococcus pentosaceus 12455 and $4 \times 10^{5} \mathrm{cfu} / \mathrm{g}$ of Lactobacillus buchneri 40788 (BB) or at twice the recommended rate (DBB). Pioneer 11C33 inoculant was applied at the recommended rate of $1.1 \mathrm{mg} / \mathrm{kg}$ fresh forage to supply $1 \times 10^{5} \mathrm{cfu} / \mathrm{g}$ of a mixture of Lactobacillus plantarum, L. buchneri, and Enteroccocus faecium $(\mathrm{PN})$ or at twice the recommended rate (DPN). Each treatment was applied in quadruplicate and the treated forages were ensiled within 20-L mini silos for $135 \mathrm{~d}$ at 18 to $35^{\circ} \mathrm{C}$. Molasses-treated silages had greater ash and starch concentrations than CON silages and greater lactate and ethanol concentrations than other silages. Like CON silages, MOL silages had high yeast counts $\left(>10^{5} \mathrm{cfu} / \mathrm{g}\right)$; consequently, they deteriorated within 30 $\mathrm{h}$ as shown by temperature increase. Inoculant-treated silages had lower lactate to acetate ratios than CON or MOL silages largely because they had greater acetate concentrations. Consequently, all inoculant-treated silages had fewer yeasts $\left(<10^{5} \mathrm{cfu} / \mathrm{g}\right)$ and were more stable $(>30 \mathrm{~h})$ than $\mathrm{CON}$ and MOL silages. When applied at recommended rates, $\mathrm{PN}$ and $\mathrm{BB}$ had similar effects on silage chemical composition, fermentation, fungal counts, and aerobic stability, except for a lower lactate concentration in PN silages. Concentrations of VFA, and $\mathrm{NH}_{3}-\mathrm{N}, \mathrm{pH}$, and extent of aerobic stability
\end{abstract}

\footnotetext{
Received July 12, 2008.

Accepted October 31, 2008.

${ }^{1}$ Corresponding author: adesogan@ufl.edu

${ }^{2}$ Current address: Department of Animal Science, Gyeongsang National University, Gajwa 900, Jinju 660-701, South Korea.
}

were similar for PN, DPN, BB, and DBB silages. However, lactate concentration was greater in DPN than in PN. In conclusion, MOL application increased ethanol and lactate concentration and did not improve aerobic stability. Both dual-purpose inoculants made the fermentation more heterolactic and thereby improved the aerobic stability of corn silage. Doubling the rate of application of either inoculant did not further improve fermentation or aerobic stability.

Key words: aerobic stability, silage, Lactobacillus buchneri, molasses

\section{INTRODUCTION}

Inoculants containing homofermentative bacteria reduce nutrient losses in ensiled forages by increasing the rate of lactate production and acidification. However, use of such inoculants can predispose silages to aerobic deterioration because they result in relatively greater levels of residual water-soluble carbohydrates (WSC) and lactate, which are used as growth substrates by spoilage-causing yeasts and molds (Weinberg and Muck, 1996). In contrast, inoculants containing heterofermentative Lactobacillus buchneri alone typically improve the aerobic stability of silages, but often slightly increase DM losses and pH (Driehuis et al., 2001; Adesogan et al., 2003; Kleinschmit and Kung, 2006a). Dualpurpose inoculants containing homofermentative and heterofermentative bacteria were recently developed to overcome the limitations of inoculants containing either type of bacteria alone. Dual-purpose inoculants improved the fermentation of pea-wheat intercrops but did not improve their aerobic stability (Adesogan and Salawu, 2004). In contrast, several workers found that such inoculants improved the fermentation and aerobic stability of corn, sorghum, bermudagrass, and ryegrass silage (Driehuis et al., 2001; Filya, 2003; Adesogan et al., 2004). However, dual-purpose inoculants produced by different companies have not been compared. Furthermore, they have not been tested on corn silage produced in warm, humid conditions that can adversely affect silage fermentation (Ashbell et al., 2002; Kim 
and Adesogan, 2006). In Florida, ineffectiveness of silage inoculants has been anecdotally blamed on the use of application rates more suited to silages produced in cooler, less humid states where the inoculants were developed. Although such assertions have not been validated by independent research, some producers have been advised to double the recommended inoculant application rates to guarantee efficacy. Therefore, one of the objectives of this study was to compare the effect of applying 2 dual-purpose inoculants from different companies at the recommended rate or at twice the recommended rate on the fermentation and aerobic stability of corn silage produced in Florida. A further concern among Florida producers is that the concentration of fermentable sugars in corn hybrids grown in subtropical climates is inadequate for optimal fermentation. Of 134 corn hybrids examined in the 2005 Florida corn silage Hybrid Evaluation Trial (Adesogan, 2006), 25\% had less sugars than required (5\%; Pitt, 1990) for optimizing the fermentation of corn silage harvested at 35\% DM. High temperatures can reduce sugar deposition in corn plants by reducing the rate of photosynthesis through inactivation of ribulose 1,5-bisphosphate carboxylase/ oxygenase (Crafts-Brandner and Salvucci, 2002). Therefore, a second objective was to determine if addition of supplemental sugars from molasses would enhance the fermentation of corn silage grown in Florida.

\section{MATERIALS AND METHODS}

\section{Silage Production}

A corn hybrid (DeKalb 69-70, Monsanto, St. Louis, $\mathrm{MO}$ ) was grown at the University of Florida Plant Science Unit, harvested at the $2 / 3$ milk line stage and $39 \% \mathrm{DM}$ and chopped with a 2-row forage harvester to lengths of about $2 \mathrm{~cm}$. Chopped forages were treated with 1) deionized water (CON); 2) Blackstrap sugar cane molasses diluted with water at the factory to reduce viscosity (MOL; United States Sugar Corp., Clewiston, FL); 3) Buchneri 500 inoculant (BB; Lallemand Animal Nutrition, Milwaukee, WI); or 4) Pioneer 11C33 inoculant (PN; Pioneer Hi-Bred International, Des Moines, IA). Buchneri 500 and Pioneer 11C33 inoculants were applied at recommended rates; that is, $8(\mathrm{BB})$ and $1.1(\mathrm{PN}) \mathrm{mg} / \mathrm{kg}$ of fresh forage, respectively, and at twice the recommended rates; that is, $16(\mathbf{D B B})$ and $2.2(\mathbf{D P N}) \mathrm{mg} / \mathrm{kg}$ of fresh forage, respectively. The molasses contained $75 \% \mathrm{DM}, 5 \% \mathrm{CP}$, and $42 \%$ WSC on a DM basis and it was applied at $3 \%$ of forage DM. According to the label, PN supplied 1 $\times 10^{5} \mathrm{cfu} / \mathrm{g}$ of fresh forage of a mixture of Lactobacillus plantarum, L. buchneri, and Enteroccocus faecium, whereas BB supplied $1 \times 10^{5} \mathrm{cfu} / \mathrm{g}$ of Pediococcus pen- tosaceus $12455,4 \times 10^{5} \mathrm{cfu} / \mathrm{g}$ of $L$. buchneri 40788 , as well as $\beta$-glucanase (EC 3.2.1.6), xylanase (EC 3.2.1.8), and mannanase (EC 3.2.1.78) with respective activities of at least 30, 864, and $14 \mathrm{mg}$ of glucose liberated/ min per gram. Activities were analyzed using dinitrosalicylic acid-based methods (Miller, 1959; Bailey et al., 1992) and assay $\mathrm{pH}$, temperature, and substrates (Megazyme International Ltd., Wicklow, Ireland) for $\beta$-glucanase, xylanase, and mannanase were $4.8,30^{\circ} \mathrm{C}$, and $\beta$-glucan; $4.7,30^{\circ} \mathrm{C}$, and birchwood xylan; and 5.3, $50^{\circ} \mathrm{C}$, and guar gum, respectively. Each additive was dissolved in $2 \mathrm{~L}$ of deionized water and sprayed in a fine mist on $120 \mathrm{~kg}$ of forage. A similar quantity of deionized water was sprayed on the untreated forages. Four replicates of each treatment were weighed $(6 \mathrm{~kg})$ into plastic bags and ensiled in 20-L macro silos at a density of $160 \mathrm{~kg}$ of $\mathrm{DM} / \mathrm{m}^{3}$ for $135 \mathrm{~d}$, giving a total of 24 silos for all treatments. At ensiling, the forage within the bags was consolidated manually to expel air, bags were secured with plastic ties, and the macro silos were sealed immediately with plastic covers. Weights of the empty and full silos were recorded, and silos were stored at ambient temperature $\left(18\right.$ to $\left.35^{\circ} \mathrm{C}\right)$ in an enclosed barn. Representative samples of the treated, unensiled forages were frozen $\left(-20^{\circ} \mathrm{C}\right)$ for subsequent laboratory analysis. At silo opening, final silo weights were recorded and the silage in the top three-fourths of each silo was removed and representative subsamples were taken for DM determination, silage juice extraction and chemical analysis, long-term storage $\left(-20^{\circ} \mathrm{C}\right)$, microbial enumeration, and aerobic stability. Samples destined for microbial analysis were heat-sealed within gas-impermeable bags (Kapak Scotch Pak, Kapak Corp., Minneapolis, MN), placed in an icebox, and dispatched on the same day to commercial laboratories for lactic acid bacteria, yeast, and mold counts. Samples remaining in the lower one-fourth of each silo were reserved for aerobic stability measurements on relatively undisturbed forage. In addition, $3 \mathrm{~kg}$ of each treated forage was ensiled at a density of $125 \mathrm{~kg}$ of $\mathrm{DM} / \mathrm{m}^{3}$ in quadruplicate within plastic bags for $1,3,5$, and $7 \mathrm{~d}$, giving 96 additional mini silos. These silages were used to examine treatment effects on fermentation indices during the first $7 \mathrm{~d}$ of ensiling.

\section{Laboratory Analysis}

Freshly treated, unensiled forages were analyzed for chemical composition and in vitro true DM digestibility (IVDMD). In addition to these measurements, d 135 silages were analyzed for aerobic stability, starch, ethanol, and yeast, mold, and lactic acid bacteria counts. To measure fermentation indices, $20 \mathrm{~g}$ of each silage was homogenized for $30 \mathrm{~s}$ in a blender with $200 \mathrm{~mL}$ of 
deionized water. The resulting suspension was filtered through 4 layers of cheesecloth, centrifuged for $20 \mathrm{~min}$ at $27,500 \times g$, and the pellet was discarded. Samples of the supernatant were reserved for $\mathrm{pH}$, lactate, VFA, ethanol, and $\mathrm{NH}_{3}-\mathrm{N}$ analyses. The $\mathrm{pH}$ was measured using a pH meter (Corning Model 12, Corning Scientific Instruments, Medfield, MA). The DM concentrations of unensiled forage samples and silage samples were determined in a forced-draft oven set to $60^{\circ} \mathrm{C}$ for $48 \mathrm{~h}$. Dry matter recovery of d 135 silages was estimated by comparing the product of forage mass and forage DM concentration before and after ensiling for each silo. Ash was determined by placing samples in a muffle furnace set at $500^{\circ} \mathrm{C}$ for $5 \mathrm{~h}$. The anthrone reaction assay (Ministry of Agriculture, Fisheries and Food, 1986) was used to measure WSC. Ammonia-N was determined using an adaptation for the Technicon Auto Analyzer of the Noel and Hambleton (1976) method. The adaptation involved replacing titration with colorimetric $\mathrm{N}$ quantification. The methods of Van Soest et al. (1991) were used for NDF and ADF analysis and the analyses were not sequential. Amylase and sodium sulfite were used in the NDF analysis and the results were expressed on a DM basis inclusive of ash. Crude protein was calculated by multiplying $\mathrm{N}$ measurements obtained from an elemental $\mathrm{N}$ analyzer (Elementar Americas Inc., Mt. Laurel, NJ) by 6.25. In vitro true DM digestibility was determined with the method of Van Soest et al. (1966). Lactic acid, VFA, and ethanol concentrations were determined by HPLC (Muck and Dickerson, 1988). Yeasts and molds were enumerated by pour plating in Standard Methods (M124) agar to which $40 \mathrm{mg} / \mathrm{kg}$ of chloramphenicol and chlortetracycline were added (Tournas et al., 1998). Lactic acid bacteria were enumerated by pour plating in acidified de Man, Rogosa, and Sharpe agar (Hall et al., 2001). Aerobic stability was measured by placing representatively sampled (disturbed) forage $(1 \mathrm{~kg})$ from each silo into plastic bags within an open-top polystyrene box. Thermocouple wires placed at the geometric center of each silage sample were connected to data loggers that recorded hourly temperature readings for 16 d. Four additional thermocouple wires were used to measure ambient temperature. All silage samples were covered with 2 layers of cheesecloth to minimize drying and stored at room temperature $\left(21\right.$ to $\left.25^{\circ} \mathrm{C}\right)$ for $16 \mathrm{~d}$. Aerobic deterioration was denoted by a $2^{\circ} \mathrm{C}$ increase above room temperature. In addition, aerobic stability was measured on the relatively undisturbed forage by placing thermocouple wires in the forage remaining within each silo for $16 \mathrm{~d}$. The relatively disturbed and undisturbed silages were assumed to represent aerated silage in a feed bunk or on a silo face and undisturbed silage behind the silo face, respectively.

\section{Statistical Analyses}

The experiment was a completely randomized design and the data were analyzed using the GLM procedure (SAS Institute, 2005). Means separation was performed using Tukey's test with an $\alpha$ level of $P<0.05$. Tendencies were declared if $P>0.5$ but $<0.1$.

\section{RESULTS}

\section{Chemical Composition}

The chemical composition of the treated and untreated corn forages before ensiling was similar (Table 1) and the starch concentration of unensiled CON silages was $33.7 \%$. Application of MOL increased the WSC concentration of the unensiled forage by approximately 1 percentage unit. During the first $7 \mathrm{~d}$ of ensiling, $\mathrm{pH}$ and WSC concentration decreased, whereas lactate and $\mathrm{NH}_{3}-\mathrm{N}$ concentrations increased (Table 2). Only WSC, lactate, and $\mathrm{NH}_{3}-\mathrm{N}$ concentrations were affected by treatment during this period. Lactate concentrations were lowest in BB silages after $1 \mathrm{~d}$, whereas MOL silages had more lactate than PN and DPN silages after $3 \mathrm{~d}$. After 1 or $5 \mathrm{~d}$, silages treated with DPN had greater residual WSC concentration than controls, but this response was reversed after $7 \mathrm{~d}$, when DBB, PN, and DPN silages had lower residual WSC concentrations than CON. After $1 \mathrm{~d}$ of ensiling, $\mathrm{NH}_{3}-\mathrm{N}$ concentration (\% of total $\mathrm{N}$ ) was greater in DPN silage than in CON and $\mathrm{BB} ; \mathrm{NH}_{3}-\mathrm{N}$ concentration (\% of $\mathrm{DM}$ ) of DPN silages was also greater than that of CON. After $7 \mathrm{~d}$ of ensiling, $\mathrm{NH}_{3}-\mathrm{N}$ concentrations of DPN silages were greater than those of $\mathrm{CON}, \mathrm{BB}, \mathrm{PN}$, and MOL silages. After $135 \mathrm{~d}$, DBB silage had a lower DM concentration than CON, and DPN silages tended $(P=0.09)$ to have greater DM recovery than CON and DBB silages (Table 3). Control silages had lower ash concentrations than MOL, DBB, and DPN silages, likely reflecting the contribution of minerals from the additives. Control and MOL silages had greater residual WSC concentration than inoculant-treated silages. In contrast, all additivetreated silages had greater starch concentrations than the CON silage, and starch concentration was greater in $\mathrm{BB}$ and PN silages than in CON, DBB, and DPN silages. Silages treated with DBB and DPN had greater NDF concentrations than CON, BB, or MOL silages.

\section{Fermentation Indices of Corn Silage Ensiled for $135 d$}

Silage fermentation indices are shown in Table 4. Silage $\mathrm{pH}$ was slightly greater in $\mathrm{PN}$ silage than in $\mathrm{CON}$ and MOL silages, and it was slightly lower in MOL 
Table 1. Effect of applying molasses or 2 inoculants at different rates on chemical composition of corn forage before ensiling (\% of DM or as stated)

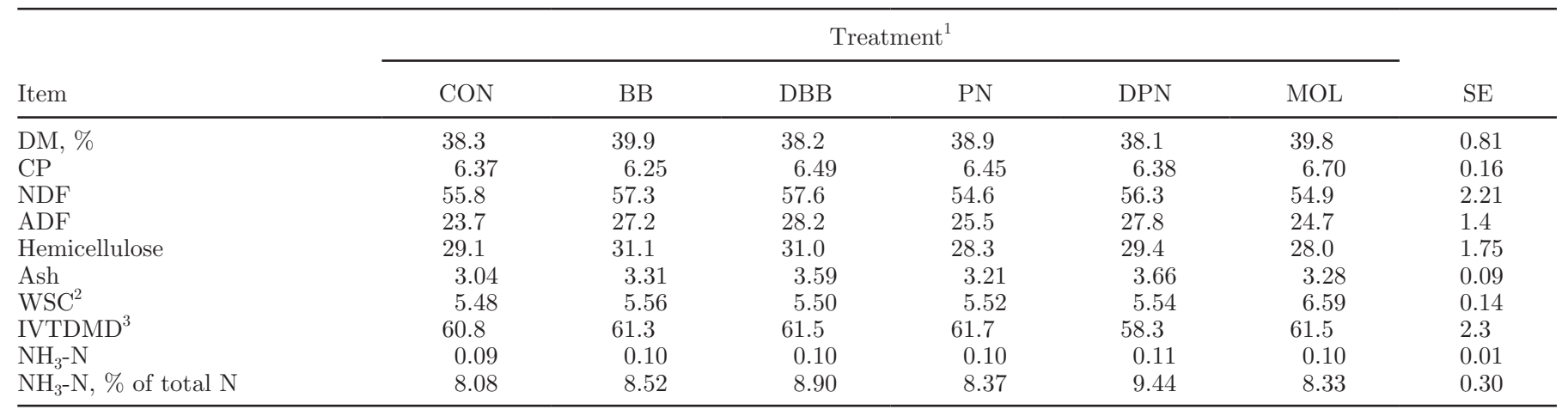

${ }^{1} \mathrm{CON}=$ no additives; $\mathrm{BB}=$ a mixture of Pediococcus pentosaceus $12455,1 \times 10^{5} \mathrm{cfu} / \mathrm{g}$, and Lactobacillus buchneri $40788,4 \times 10^{5} \mathrm{cfu} / \mathrm{g}$, applied at $8 \mathrm{mg} / \mathrm{kg} ; \mathrm{DBB}=\mathrm{BB}$ applied at $16 \mathrm{mg} / \mathrm{kg} ; \mathrm{PN}=$ a mixture containing $1 \times 10^{5} \mathrm{cfu} / \mathrm{g}$ of Lactobacillus plantarum, L. buchneri, and Enteroccocus faecium applied at $1.1 \mathrm{mg} / \mathrm{kg} ; \mathrm{DPN}=\mathrm{PN}$ applied at $2.2 \mathrm{mg} / \mathrm{kg} ; \mathrm{MOL}=$ molasses applied at $3 \%$ of DM.

${ }^{2} \mathrm{WSC}=$ water-soluble carbohydrates

${ }^{3}$ IVTDMD $=48$-h in vitro true DM digestibility.

Table 2. Effect of applying molasses or 2 inoculants at different rates on chemical composition of corn silage ensiled for $1,3,5$, and $7 \mathrm{~d}$ (\% of $\mathrm{DM}$ or as stated)

\begin{tabular}{|c|c|c|c|c|c|c|c|}
\hline Item & \multicolumn{6}{|c|}{ Treatment $^{1}$} & SEM \\
\hline \multicolumn{8}{|l|}{ Ensiled for $1 \mathrm{~d}$} \\
\hline $\mathrm{pH}$ & 6.56 & 6.54 & 6.70 & 6.75 & 6.78 & 6.68 & 0.22 \\
\hline $\mathrm{CP}$ & 6.82 & 7.02 & 6.69 & 6.62 & 6.49 & 6.51 & 0.28 \\
\hline $\mathrm{WSC}^{2}$ & $2.67^{\mathrm{b}}$ & $3.20^{\mathrm{ab}}$ & $3.62^{\mathrm{ab}}$ & $3.06^{\mathrm{ab}}$ & $3.97^{\mathrm{a}}$ & $3.27^{\mathrm{ab}}$ & 0.42 \\
\hline Lactate & $1.88^{\mathrm{a}}$ & $1.41^{\mathrm{b}}$ & $2.00^{\mathrm{a}}$ & $1.91^{\mathrm{a}}$ & $2.09^{\mathrm{a}}$ & $1.87^{\mathrm{a}}$ & 0.10 \\
\hline \multicolumn{8}{|l|}{ Ensiled for $3 \mathrm{~d}$} \\
\hline DM & 39.3 & 39.3 & 39.6 & 39.5 & 38.2 & 39.6 & 1.03 \\
\hline $\mathrm{pH}$ & 6.53 & 6.25 & 6.27 & 6.47 & 6.46 & 6.34 & 0.51 \\
\hline $\mathrm{CP}$ & 6.40 & 6.69 & 6.29 & 6.58 & 6.25 & 6.55 & 0.24 \\
\hline WSC & 1.30 & 1.61 & 1.49 & 1.50 & 1.54 & 1.59 & 0.24 \\
\hline $\mathrm{NH}_{3}-\mathrm{N}$ & 0.11 & 0.11 & 0.11 & 0.12 & 0.11 & 0.11 & 0.06 \\
\hline \multicolumn{8}{|l|}{ Ensiled for $5 \mathrm{~d}$} \\
\hline $\mathrm{CP}$ & 6.51 & 6.52 & 6.53 & 6.36 & 6.55 & 6.34 & 0.22 \\
\hline WSC & $0.89^{\mathrm{b}}$ & $1.06^{\mathrm{ab}}$ & $1.14^{\mathrm{ab}}$ & $1.03^{\mathrm{ab}}$ & $1.48^{\mathrm{a}}$ & $0.87^{\mathrm{b}}$ & 0.21 \\
\hline $\mathrm{NH}_{3}-\mathrm{N}$ & 0.11 & 0.12 & 0.11 & 0.13 & 0.12 & 0.12 & 0.08 \\
\hline $\mathrm{NH}_{3}-\mathrm{N}, \%$ of total $\mathrm{N}$ & 9.88 & 10.11 & 9.72 & 11.08 & 10.02 & 9.90 & 0.87 \\
\hline Lactate & 2.29 & 2.39 & 3.59 & 2.55 & 3.31 & 2.69 & 0.45 \\
\hline \multicolumn{8}{|l|}{ Ensiled for $7 \mathrm{~d}$} \\
\hline $\mathrm{DM}$ & 39.7 & 39.5 & 38.9 & 39.3 & 38.2 & 40.0 & 0.92 \\
\hline $\mathrm{pH}$ & 4.46 & 4.14 & 4.84 & 4.41 & 4.20 & 4.27 & 0.25 \\
\hline $\mathrm{CP}$ & 6.17 & 6.18 & 6.36 & 6.33 & 6.33 & 6.34 & 0.35 \\
\hline WSC & $1.22^{\mathrm{a}}$ & $1.10^{\mathrm{ab}}$ & $0.76^{\mathrm{b}}$ & $0.74^{\mathrm{b}}$ & $0.82^{\mathrm{b}}$ & $1.10^{\mathrm{ab}}$ & 0.12 \\
\hline $\mathrm{NH}_{3}-\mathrm{N}$ & $0.11^{\mathrm{c}}$ & $0.12^{\mathrm{bc}}$ & $0.12^{\mathrm{ab}}$ & $0.11^{\mathrm{bc}}$ & $0.13^{\mathrm{a}}$ & $0.11^{\mathrm{c}}$ & 0.05 \\
\hline $\mathrm{NH}_{3}-\mathrm{N}, \%$ of total $\mathrm{N}$ & 9.98 & 10.26 & 10.7 & 10.10 & 10.81 & 9.45 & 0.91 \\
\hline Lactate & 2.48 & 2.98 & 3.31 & 2.08 & 3.19 & 3.08 & 0.42 \\
\hline
\end{tabular}

${ }^{\mathrm{a}-\mathrm{c}}$ Within a row, means without a common superscript letter differ $(P<0.05)$.

${ }^{1} \mathrm{CON}=$ no additives; $\mathrm{BB}=$ a mixture of Pediococcus pentosaceus $12455,1 \times 10^{5} \mathrm{cfu} / \mathrm{g}$, and Lactobacillus buchneri $40788,4 \times 10^{5} \mathrm{cfu} / \mathrm{g}$, applied at $8 \mathrm{mg} / \mathrm{kg} ; \mathrm{DBB}=\mathrm{BB}$ applied at $16 \mathrm{mg} / \mathrm{kg} ; \mathrm{PN}=$ a mixture containing $1 \times 10^{5} \mathrm{cfu} / \mathrm{g}$ of Lactobacillus plantarum, L. buchneri, and Enteroccocus faecium applied at $1.1 \mathrm{mg} / \mathrm{kg} ; \mathrm{DPN}=\mathrm{PN}$ applied at $2.2 \mathrm{mg} / \mathrm{kg} ; \mathrm{MOL}=$ molasses applied at $3 \%$ of DM.

${ }^{2} \mathrm{WSC}=$ water-soluble carbohydrates. 
Table 3. Effect of applying molasses or 2 inoculants at different rates on chemical composition of corn silage ensiled for $135 \mathrm{~d}$ (\% of DM or as stated)

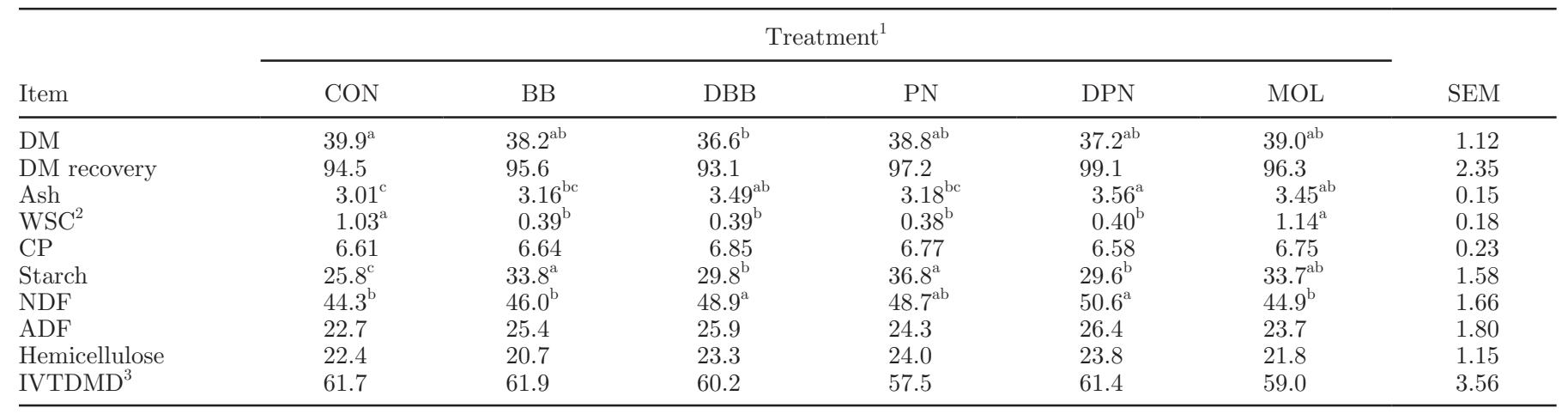

${ }^{\mathrm{a}-\mathrm{c}}$ Within a row, means without a common superscript letter differ $(P<0.05)$.

${ }^{1} \mathrm{CON}=$ no additives; $\mathrm{BB}=$ a mixture of Pediococcus pentosaceus $12455,1 \times 10^{5} \mathrm{cfu} / \mathrm{g}$, and Lactobacillus buchneri $40788,4 \times 10^{5} \mathrm{cfu} / \mathrm{g}$, applied at $8 \mathrm{mg} / \mathrm{kg} ; \mathrm{DBB}=\mathrm{BB}$ applied at $16 \mathrm{mg} / \mathrm{kg} ; \mathrm{PN}=$ a mixture containing $1 \times 10^{5} \mathrm{cfu} / \mathrm{g}$ of Lactobacillus plantarum, L. buchneri, and Enteroccocus faecium applied at $1.1 \mathrm{mg} / \mathrm{kg} ; \mathrm{DPN}=\mathrm{PN}$ applied at $2.2 \mathrm{mg} / \mathrm{kg} ; \mathrm{MOL}=$ molasses applied at $3 \%$ of DM.

${ }^{2} \mathrm{WSC}=$ water-soluble carbohydrates.

${ }^{3} \mathrm{IVTDMD}=48$-h in vitro true dry matter digestibility.

silage than BB silage. Nevertheless, inoculant-treated silages had similar $\mathrm{pH}$ values. Silages treated with MOL had lower $\mathrm{NH}_{3} \mathrm{~N}$ (\% of DM) than DBB silages, and lower $\mathrm{NH}_{3}-\mathrm{N}$ (\% of total $\mathrm{N}$ ) than DPN silages. Lactate concentration was greatest in MOL silages and lowest in PN silages. Total VFA concentration was greater in DPN versus CON silages. Acetate concentrations were greater in $\mathrm{BB}, \mathrm{PN}$, and $\mathrm{DPN}$ silages than in $\mathrm{CON}$ and MOL silages, and propionate concentration was greater in PN than in DBB silage. Lactate to acetate ratio was lower in all inoculant-treated silages than in $\mathrm{CON}$ and MOL silages, but the only difference among inoculanttreated silages was a lower ratio for $\mathrm{PN}$ than for $\mathrm{DBB}$ silages. Ethanol concentration was greater in MOL silages than in other silages.

\section{Microbial Counts and Aerobic Stability of Corn Silage Ensiled for $135 d$}

Lactic acid bacteria counts were unaffected by treatment. Mold counts were greater in MOL versus PN silages, but otherwise counts were similar. Yeasts were at least $25 \%$ fewer in all inoculant-treated silages than in CON and MOL silages, and PN and DPN silages had fewer yeasts than DBB silage. Disturbed CON and MOL silages were only stable for $25 \mathrm{~h}$, whereas inocu-

Table 4. Effect of applying molasses or 2 inoculants at different rates on fermentation indices and microbial counts of corn silage ensiled for $135 \mathrm{~d}(\%$ of DM or as stated)

\begin{tabular}{|c|c|c|c|c|c|c|c|}
\hline \multirow[b]{2}{*}{ Item } & \multicolumn{6}{|c|}{ Treatment $^{1}$} & \multirow[b]{2}{*}{ SEM } \\
\hline & $\mathrm{CON}$ & $\mathrm{BB}$ & DBB & $\mathrm{PN}$ & $\mathrm{DPN}$ & MOL & \\
\hline $\mathrm{pH}$ & $3.84^{\mathrm{bc}}$ & $3.96^{\mathrm{ab}}$ & $3.93^{\mathrm{abc}}$ & $4.06^{\mathrm{a}}$ & $3.94^{\mathrm{abc}}$ & $3.81^{\mathrm{c}}$ & 0.06 \\
\hline $\mathrm{NH}_{3}-\mathrm{N}$ & $0.14^{\mathrm{ab}}$ & $0.16^{\mathrm{ab}}$ & $0.16^{\mathrm{a}}$ & $0.16^{\mathrm{ab}}$ & $0.16^{\mathrm{ab}}$ & $0.13^{\mathrm{b}}$ & 0.01 \\
\hline $\mathrm{NH}_{3}-\mathrm{N}, \%$ of total $\mathrm{N}$ & $11.5^{\mathrm{ab}}$ & $12.7^{\mathrm{ab}}$ & $13.0^{\mathrm{ab}}$ & $12.7^{\mathrm{ab}}$ & $13.1^{\mathrm{a}}$ & $9.3^{\mathrm{b}}$ & 1.24 \\
\hline Lactate (La) & $2.46^{\mathrm{b}}$ & $2.20^{\mathrm{b}}$ & $2.17^{\mathrm{b}}$ & $1.16^{\mathrm{c}}$ & $2.30^{\mathrm{b}}$ & $3.51^{\mathrm{a}}$ & 0.23 \\
\hline Total VFA & $3.14^{\mathrm{b}}$ & $5.32^{\mathrm{ab}}$ & $4.18^{\mathrm{ab}}$ & $5.06^{\mathrm{ab}}$ & $6.14^{\mathrm{a}}$ & $3.85^{\mathrm{ab}}$ & 1.10 \\
\hline Acetate (Ac) & $0.68^{\mathrm{b}}$ & $2.44^{\mathrm{a}}$ & $1.52^{\mathrm{ab}}$ & $2.45^{\mathrm{a}}$ & $2.13^{\mathrm{a}}$ & $0.90^{\mathrm{b}}$ & 0.40 \\
\hline Propionate & $0.64^{\mathrm{ab}}$ & $0.74^{\mathrm{ab}}$ & $0.57^{\mathrm{b}}$ & $0.80^{\mathrm{a}}$ & $0.78^{\mathrm{ab}}$ & $0.75^{\mathrm{ab}}$ & 0.10 \\
\hline La:Ac ratio & $3.63^{\mathrm{a}}$ & $0.91^{\mathrm{bc}}$ & $1.44^{\mathrm{b}}$ & $0.46^{\mathrm{c}}$ & $1.21^{\mathrm{bc}}$ & $3.90^{\mathrm{a}}$ & 0.27 \\
\hline Ethanol & $0.94^{\mathrm{b}}$ & $0.70^{\mathrm{b}}$ & $0.67^{\mathrm{b}}$ & $0.59^{\mathrm{b}}$ & $1.09^{\mathrm{b}}$ & $1.74^{\mathrm{a}}$ & 0.21 \\
\hline Lactic acid bacteria, log $\mathrm{cfu} / \mathrm{g}$ & 7.58 & 8.05 & 7.37 & 7.22 & 7.98 & 7.17 & 0.42 \\
\hline Mold, $\log \mathrm{cfu} / \mathrm{g}$ & $3.48^{\mathrm{ab}}$ & $3.10^{\mathrm{ab}}$ & $3.20^{\mathrm{ab}}$ & $2.87^{\mathrm{b}}$ & $3.28^{\mathrm{ab}}$ & $3.90^{\mathrm{a}}$ & 0.37 \\
\hline Yeast, $\log \mathrm{cfu} / \mathrm{g}$ & $5.95^{\mathrm{a}}$ & $3.53^{\mathrm{bc}}$ & $4.47^{\mathrm{b}}$ & $2.00^{\mathrm{c}}$ & $2.00^{\mathrm{c}}$ & $6.13^{\mathrm{a}}$ & 0.58 \\
\hline
\end{tabular}

${ }^{\mathrm{a}-\mathrm{c}}$ Within a row, means without a common superscript letter differ $(P<0.05)$.

${ }^{1} \mathrm{CON}=$ no additives; $\mathrm{BB}=$ a mixture of Pediococcus pentosaceus $12455,1 \times 10^{5} \mathrm{cfu} / \mathrm{g}$, and Lactobacillus buchneri $40788,4 \times 10^{5} \mathrm{cfu} / \mathrm{g}$, applied at $8 \mathrm{mg} / \mathrm{kg} ; \mathrm{DBB}=\mathrm{BB}$ applied at $16 \mathrm{mg} / \mathrm{kg} ; \mathrm{PN}=$ a mixture containing $1 \times 10^{5} \mathrm{cfu} / \mathrm{g}$ of Lactobacillus plantarum, L. buchneri, and Enteroccocus faecium applied at $1.1 \mathrm{mg} / \mathrm{kg} ; \mathrm{DPN}=\mathrm{PN}$ applied at $2.2 \mathrm{mg} / \mathrm{kg} ; \mathrm{MOL}=$ molasses applied at $3 \%$ of DM. 
lant-treated silages were stable for an additional 35 to $71 \mathrm{~h}$ (Figure 1). Disturbed silages treated with DPN were more stable than those treated with $\mathrm{BB}$ or DBB. However, doubling the rate of application of either inoculant did not $(P>0.05)$ improve aerobic stability. Undisturbed silages were more stable than disturbed silages. Nevertheless, inoculant-treated undisturbed silages were more stable than undisturbed $\mathrm{CON}$ and MOL silages by more than $220 \mathrm{~h}$. Most inoculanttreated undisturbed silages had not deteriorated by the end of the 16-d temperature-monitoring period.

\section{DISCUSSION}

\section{Chemical Composition}

The chemical composition of the corn forages and silages were similar to those harvested previously in Florida (Adesogan, 2006; Kim and Adesogan, 2006). The WSC concentration of all forages was lower than the typical range for corn silage (8-30\%; Pitt, 1990) but they were similar to that $(4-5 \%)$ required for maximizing $\mathrm{pH}$ reduction in corn forage harvested at 35 to $40 \%$ DM (Pitt, 1990). Changes in pH, and concentrations
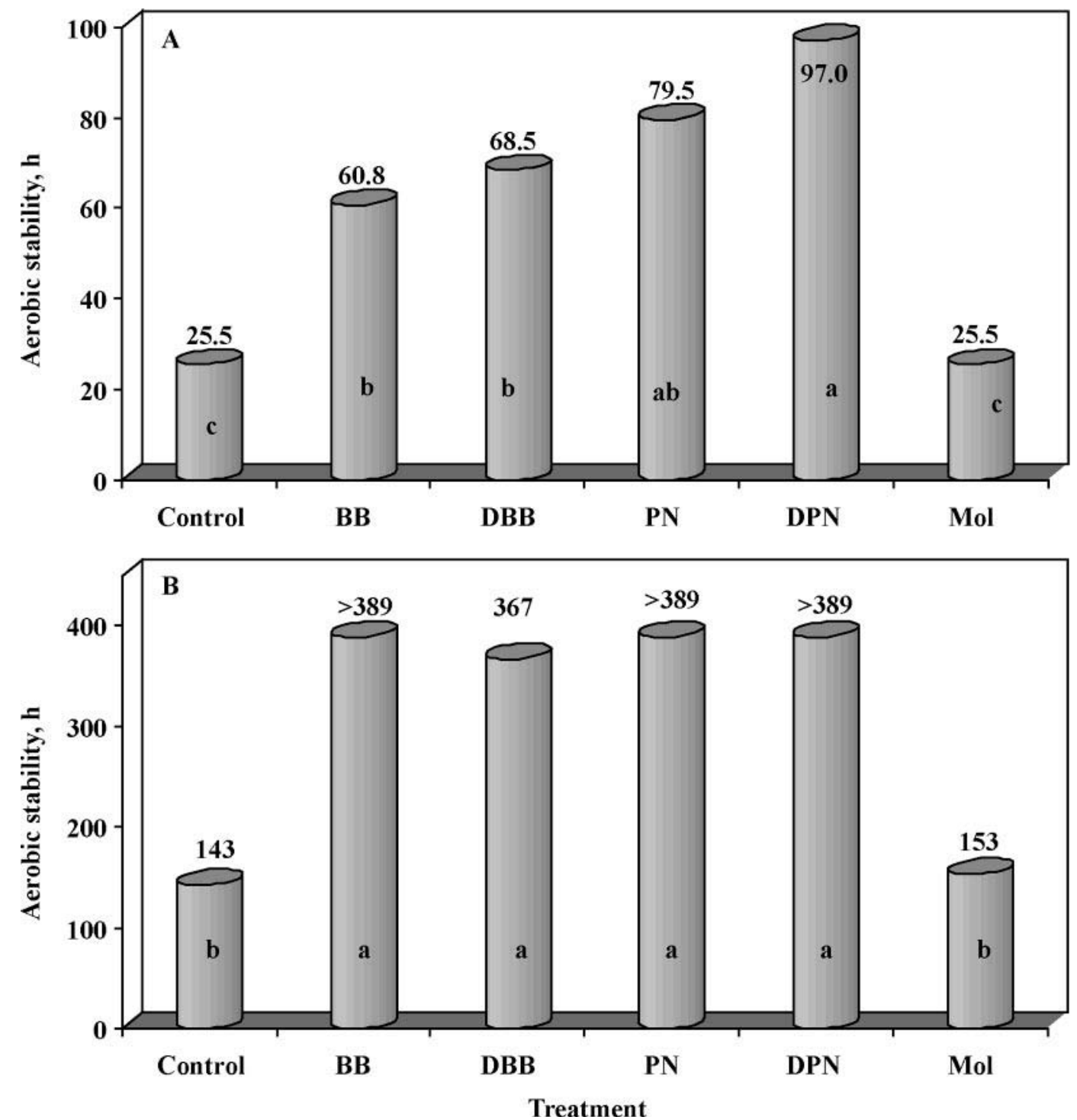

Figure 1. Effect of applying molasses or 2 inoculants at different rates on aerobic stability of relatively disturbed (panel A; SEM = 10.6) and undisturbed (panel B; SEM = 53) silages ensiled for $135 \mathrm{~d}$. ${ }^{\mathrm{a}-\mathrm{c}}$ Bars with different letters differ, $P<0.05$. CON $=$ no additives; BB $=$ a mixture of Pediococcus pentosaceus $12455,1 \times 10^{5} \mathrm{cfu} / \mathrm{g}$, and Lactobacillus buchneri $40788,4 \times 10^{5} \mathrm{cfu} / \mathrm{g}$, applied at $8 \mathrm{mg} / \mathrm{kg}$; DBB $=\mathrm{BB}$ applied at 16 $\mathrm{mg} / \mathrm{kg} ; \mathrm{PN}=$ a mixture containing $1 \times 10^{5} \mathrm{cfu} / \mathrm{g}$ of Lactobacillus plantarum, L. buchneri, and Enteroccocus faecium applied at $1.1 \mathrm{mg} / \mathrm{kg} ;$ DPN $=\mathrm{PN}$ applied at $2.2 \mathrm{mg} / \mathrm{kg} ; \mathrm{Mol}=$ molasses applied at $3 \%$ of DM. 
of WSC and $\mathrm{NH}_{3}-\mathrm{N}$ during the fermentation reflected microbial fermentation of WSC into lactic acid and microbial proteolysis, respectively. Fermentation product concentrations of CON silages were normal for wellpreserved corn silages (Allen et al., 2003) except for relatively low lactate concentrations, which may reflect the maturity and relatively low WSC concentrations of the forages. Concentrations of hemicellulose and NDF decreased markedly between d 0 and 135 , whereas ADF concentration did not. This may have been because of enzymatic or acid hydrolysis of the more digestible cellwall fractions during the fermentation. Rooke and Hatfield (2003) cited several studies in which the cell-wall fraction was modified by such hydrolases and stated that hydrolases are more likely to improve silage quality when the WSC concentration is low.

\section{Effects of Molasses Application}

The WSC concentration of the corn forage was lower than normal (8-30\%), but at 5\%, it was high enough to optimize the fermentation of corn silage (Pitt, 1990). Therefore, corn forages with lower WSC concentrations would have been more ideal candidates for examining the effect of MOL addition. Nevertheless, the 1-percentage-unit increase in WSC due to MOL application represented a $20 \%$ increase over the WSC concentration of the CON silage, and resulted in a greater starch concentration after $135 \mathrm{~d}$ of ensiling. This was probably because the sugars supplied by MOL reduced the need for starch hydrolysis to provide fermentable substrates. As in other studies (McDonald et al., 1991; Adesogan et al., 2004), MOL application increased lactate concentration substantially (43\%) and increased ethanol concentration by a greater margin (85\%). The increased ethanol production reflects glucose fermentation by heterofermentative bacteria and yeasts (McDonald et al., 1991) and is undesirable because when excessive, it can reduce acid production and is often accompanied by loss of DM as $\mathrm{CO}_{2}$ (Rooke and Hatfield, 2003). Application of MOL did not affect counts of yeasts or molds that cause spoilage. Nevertheless, high yeast counts $\left(\geq 10^{5} \mathrm{cfu} / \mathrm{g}\right)$ in MOL and CON silages resulted in rapid deterioration after aerobic exposure.

\section{Effects of Inoculants}

After $7 \mathrm{~d}$ of ensiling, most inoculant treatments had lower residual WSC concentrations than CON silages, indicating that the WSC in inoculant-treated forages was used more exhaustively for the fermentation. This trend was more evident after $135 \mathrm{~d}$ of ensiling and it was associated with greater starch concentrations in inoculated silages. Inoculant-treated silages had lower lactate to acetate ratios than $\mathrm{CON}$ or MOL silages because inoculant addition generally increased acetate concentration and decreased or did not affect lactate concentration. The greater acetate concentration in most inoculated silages is attributable to the presence of the heterofermentative L. buchneri in the inoculants, which typically enhances acetic acid production, thereby reducing yeast counts and enhancing aerobic stability (Driehuis et al., 1996, 2001). In agreement, all inoculant-treated silages had at least $25 \%$ fewer yeasts than CON or MOL silages. Therefore, compared with CON silages, inoculant-treated disturbed silages were stable for 35 to 71 additional hours and inoculant-treated undisturbed silages were stable at least 224 more hours. This suggests that dual-purpose L. buchneri inoculants can enhance the stability of less-aerated silage behind the silo face as well as aerated silage in feedbunks or on silo faces. Others have shown that inoculants containing a mixture of homofermentative and heterofermentative (L. buchneri) bacteria improved the aerobic stability of corn silage (Weinberg et al., 2002; Filya, 2003) though recent results suggest that this effect may vary with ensiling duration (Kleinschmit and Kung, 2006b).

\section{Comparison Among Inoculants}

Silages treated with PN had the lowest lactate concentration and therefore had a greater $\mathrm{pH}$ than CON silages. However, this $\mathrm{pH}$ difference is probably insignificant from a practical standpoint. Other than a lower propionate concentration in $\mathrm{DBB}$ versus $\mathrm{PN}$ silages, there were no other differences among the fermentation indices of inoculant-treated silages. Furthermore, inoculants had similar effects on yeast and mold counts except for greater yeast counts in DBB versus PN and DPN silages, which reflected relatively lower concentrations of strong antifungal acids (acetate and propionate) in DBB. Among disturbed silages, DPN was more stable than $\mathrm{DBB}$ and $\mathrm{BB}$ reflecting, in part, differences in yeast counts of these forages. Therefore, despite their different bacterial compositions and sources, PN and BB had similar effects on silage chemical composition, fermentation, fungal counts, and aerobic stability, except for a lower lactate concentration in PN silages. Silages treated with DBB and DPN also had similar chemical composition, fermentation indices, and mold counts, but DPN silages had fewer yeasts and were more stable than DBB silages.

Compared with the recommended rate, doubling the application rate of either inoculant did not affect concentrations of most chemical components or fermentation indices, fungal counts, or aerobic stability. Notable exceptions were that doubling the rate of PN application increased ash and lactate and reduced starch 
concentrations. Doubling the rate of $\mathrm{BB}$ application also reduced starch and increased NDF concentration. Therefore, the only desirable effect of doubling the application rate was a slight increase in lactate concentration of PN silages, which did not justify the greater rate of inoculant application.

\section{CONCLUSIONS}

This study shows that application of 2 dual-purpose inoculants to corn silage made the fermentation more heterolactic by increasing acetate production and thereby increasing aerobic stability. Despite their different sources and bacterial compositions, both inoculants had similar effects on silage chemical composition, fermentation characteristics, and aerobic stability when applied at the recommended rate. Doubling the rate of application of either inoculant was not more effective at improving silage fermentation, quality, or aerobic stability than using the recommended rate. Molasses application increased lactate and ethanol concentration and did not improve aerobic stability.

\section{ACKNOWLEDGMENTS}

We gratefully acknowledge the funding of this project by the Southeast Milk Check-Off, Lallemand Animal Nutrition (Milwaukee, WI), and Pioneer Hi-Bred, a DuPont Business (Des Moines, IA).

\section{REFERENCES}

Adesogan, A. T. 2006. Factors affecting corn silage quality in hot humid climates. Pages 108-127 in Proc. 17th Florida Rumin. Nutr. Conf., Gainesville, FL.

Adesogan, A. T., N. Krueger, M. B. Salawu, D. B. Dean, and C. R. Staples. 2004. The influence of treatment with dual purpose bacterial inoculants or soluble carbohydrates on the fermentation and aerobic stability of bermudagrass. J. Dairy Sci. 87:34073416.

Adesogan, A. T., and M. B. Salawu. 2004. Effect of applying formic acid, heterolactic bacteria or homolactic and heterolactic bacteria on the fermentation of bi-crops of peas and wheat. J. Sci. Food Agric. 84:983-992.

Adesogan, A. T., M. B. Salawu, A. B. Ross, D. R. Davies, and A. E. Brooks. 2003. Effect of Lactobacillus buchneri, L. fermentum or Leuconostoc mesenteroides inoculants or a chemical additive on the fermentation, aerobic stability and nutritive value of crimped wheat grains. J. Dairy Sci. 86:1789-1796.

Allen, M. S., J. G. Coors, and G. W. Roth. 2003. Corn silage. Pages 547-608 in Silage Science and Technology. D. R. Buxton, R. E. Muck and J. H. Harrison, ed. Am. Soc. Agron., Crop Sci. Soc. Am., Soil Sci. Soc. Am., Madison, WI.

Ashbell, G., Z. G. Weinberg, Y. Hen, and I. Filya. 2002. The effects of temperature on the aerobic stability of wheat and corn silages. J. Ind. Microbiol. Biotechnol. 28:261-263.

Bailey, M. J., P. Biely, and K. Poutanene. 1992. Interlaboratory testing of methods for assay of xylanase activity. J. Biotechnol. 23:257-270.
Crafts-Brandner, S. J., and M. E. Salvucci. 2002. Sensitivity of photosynthesis in a $\mathrm{C} 4$ plant, maize, to heat stress. Plant Physiol. 129:1773-1780.

Driehuis, F., S. J. W. H. O. Elferink, and P. G. Van Wikselaar. 2001. Fermentation characteristics and aerobic stability of grass silage inoculated with Lactobacillus buchneri, with or without homofermentative lactic acid bacteria. Grass Forage Sci. 56:330343.

Driehuis, F., S. F. Spoelstra, S. C. J. Cole, and R. Morgan. 1996. Improving aerobic stability by inoculation with Lactobacillus buchneri. Pages 106-107 in Proc. XI Int. Silage Conf. Univ. Wales, Aberystwyth, UK.

Filya, I. 2003. The effect of Lactobacillus buchneri and Lactobacillus plantarum on the fermentation, aerobic stability, and ruminal degradability of low dry matter corn and sorghum silages. J. Dairy Sci. 86:3575-3581.

Hall, P. A., L. Ledenbach, and R. S. Flowers. 2001. Acid-producing microorganisms (Method 19.522). Pages 201-206 in Compendium of Methods for the Microbiological Examination of Foods. F. P. Downes, and K. E. Ito, ed. American Public Health Association, Washington, DC.

Kim, S. C., and A. T. Adesogan. 2006. Influence of ensiling temperature, simulated rainfall, and delayed sealing on fermentation characteristics and aerobic stability of corn silage. J. Dairy Sci. 89:3122-3132.

Kleinschmit, D. H., and L. Kung Jr. 2006a. A meta-analysis of the effects of Lactobacillus buchneri on the fermentation and aerobic stability of corn and grass and small-grain silages. J. Dairy Sci. 89:4005-4013.

Kleinschmit, D. H., and L. Kung Jr. 2006b. The effects of Lactobacillus buchneri 40788 and Pediococcus pentosaceus R1094 on the fermentation of corn silage. J. Dairy Sci. 89:3999-4004.

McDonald, P., N. Henderson, and S. Heron. 1991. The Biochemistry of Silage. 2nd ed. Chalcombe Publications, Marlow, UK.

Miller, G. A. 1959. Use of dinitrosalicylic acid for determination of reducing sugars. Anal. Chem. 31:426-428.

Ministry of Agriculture, Fisheries and Food. 1986. The Analysis of Agricultural Materials. Reference Book 427. HMSO, London, UK.

Muck, R. E., and J. T. Dickerson. 1988. Storage temperature effects on proteolysis in alfalfa silage. Trans. ASAE 31:1005-1009.

Noel, R. J., and L. G. Hambleton. 1976. Collaborative study of a semiautomated method for determination of crude protein in animal feeds. J. Assoc. Off. Anal. Chem. 59:134-140.

Pitt, R. E. 1990. Silage and hay preservation. NRAES-5. Northeast Reg. Agric. Eng. Service. Ithaca, NY.

Rooke, J. A., and R. D. Hatfield. 2003. Biochemistry of ensiling. Pages 95-140 in Silage Science and Technology. D. R. Buxton, R. E. Muck and J. H. Harrison, ed. Am. Soc. Agron., Crop Sci. Soc. Am., Soil Sci. Soc. Am., Madison, WI.

SAS Institute. 2005. User's Guide: Statistics. SAS Inst., Inc., Cary, $\mathrm{NC}$

Tournas, V., M. E. Stack, P. B. Mislivec, H. A. Koch, and R Bandler. 1998. Yeasts, molds and mycotoxins. Food and Drug Administration Bacteriological Analytical Manual. AOAC International, Gaithersburg, MD.

Van Soest, P. J., J. B. Robertson, and B. A. Lewis. 1991. Methods for dietary fiber, neutral detergent fiber and non-starch polysaccharides in relation to animal nutrition. J. Dairy Sci. 74:3568-3597.

Van Soest, P. J., R. H. Wine, and L. A. Moore. 1966. Estimation of the free digestibility of forages by the in vitro digestion of cell wails. Page 438 in Proc. 10th Intl. Grassl. Congr., Helsinki, Finland.

Weinberg, Z. G., G. Ashbell, Y. Hen, G. Szakacs, and I. Filya. 2002. Ensiling whole-crop wheat and corn in large containers with Lactobacillus plantarum and Lactobacillus buchneri. J. Ind. Microbiol. Biol. 28:7-11.

Weinberg, Z. G., and R. E. Muck. 1996. New trends and opportunities in the development and use of inoculants for silage. FEMS Microbiol. Rev. 19:53-68. 